\title{
STUDI LITERATUR PENGARUH PEMBERIAN EKSTRAK KEMANGI (OCIMUM BASILICUM L.) TERHADAP KADAR SGOT DAN SGPT PADA TIKUS PUTIH JANTAN GALUR WISTAR YANG DIBERI DIET TINGGI LEMAK
}

\author{
${ }^{1}$ Dita Fitriani, ${ }^{2}$ Neno Fitriyani Hasbie, ${ }^{3}$ Toni Prasetya, ${ }^{4}$ Ferza Rusdiansyah \\ ${ }^{1}$ Departemen Fisiologi Fakultas Kedokteran Universitas Malahayati \\ ${ }^{2}$ Departemen Kesehatan Masyarakat Fakultas Kedokteran Universitas Malahayati \\ ${ }^{3}$ Departemen Penyakit Dalam Rumah Sakit Pertamina Bintang Amin Lampung \\ ${ }^{4}$ Program Studi Kedokteran Fakultas Kedokteran Universitas Malahayati \\ 12Dita@malahayati.ac.id, 2neno_hasbie@yahoo.com, ${ }^{3}$ ferzarusdiansyah@gmail.com
}

\begin{abstract}
Fatty liver (fatty liver) or Non-Alcoholic Fatty Liver Disease (NAFLD) is an excessive accumulation of fat (lipids) in liver cells. Fatty liver is generally associated with metabolic syndrome, obesity, diabetes, and hyperlipidemia. Insulin resistance causes an increase in the entry of Free Fatty Acids (FFA) into the liver and occurs due to the failure of insulin to suppress hormone-sensitive lipases. Basil contains chemical compounds such as phenolic compounds and flavonoids that act as antioxidants that can ward off free radicals. Experimental animals use mice because they have physiological similarities to humans and are easy to keep experimental animals. This study aims to determine the effect of basil extract (Ocimum basilicum L.), the effective dose and the duration of the effective dose in reducing SGOT and SGPT levels. The research design used was a descriptive research design. Literature review using the PubMed database and ncbi.mlm.nih.gov using keywords used in data searches to search for journals related to basil extract, SGOT, SGPT, rats, and high-fat diets. The results of the research from 8 journals that have been reviewed found that the levels of SGOT and SGPT had decreased significantly. Basil extract (Ocimum basilicum L.) has been proven preclinically and clinically to reduce AST and ALT levels. The conclusion that can be drawn is that the extract of basil (Ocimum basilicum L.) can reduce levels of SGOT and SGPT.
\end{abstract}

Keywords : Basil Extract, High Fat Diet, NAFLD, SGOT, SGPT, White Rat

\begin{abstract}
ABSTRAK
Perlemakan hati (fatty liver) atau Non-Alcoholic Fatty Liver Disease (NAFLD) merupakan pengumpulan lemak (lipid) yang berlebihan di dalam sel-sel hati. Perlemakan hati umunya dikaitkan dengan sindrom metabolik, obesitas, diabetes, dan hyperlipidemia. Resistensi insulin menyebabkan peningkatan masuknya Free Fatty Acids (FFA) ke dalam hati dan terjadi karena kegagalan insulin untuk menekan lipase yang sensitif terhadap hormon. Kemangi memiliki kandungan senyawa kimia seperti senyawa fenolik dan flavonoid berperan sebagai antioksidan yang dapat menangkal radikal bebas. Hewan coba menggunakan tikus dikarenakan mempunyai kemiripan fisiologis dengan manusia dan termasuk hewan coba yang mudah dipelihara. Penelitian ini bertujuan untuk mengetahui pengaruh pemberian ekstrak kemangi (Ocimum basilicum L.), dosis yang efektif dan lama pemberian dosis efektif dalam menurunkan kadar SGOT dan SGPT. Desain penelitian yang digunakan adalah desain penelitian deskriptif. Studi pustaka (literature review) menggunakan database PubMed dan ncbi.mlm.nih.gov dengan menggunakan kata kunci yang digunakan dalam pencarian data untuk menelusuri jurnal yang terkait dengan ekstrak kemangi, SGOT, SGPT, tikus, dan diet tinggi lemak. Hasil penelitian dari 8 jurnal yang telah ditelaah didapatkan bahwa kadar SGOT dan SGPT mengalami penurunan yang signifikan. Ekstrak kemangi (Ocimum basilicum L.) terbukti secara preklinis dan klinis mampu menurunkan kadar SGOT dan SGPT. Kesimpulan yang dapat diambil bahwasannya ekstrak kemangi (Ocimum basilicum L.) dapat menurunkan kadar SGOT dan SGPT.
\end{abstract}

Kata Kunci : Ekstrak Kemangi, Diet Tinggi Lemak, NAFLD, SGOT, SGPT, Tikus Puth 


\section{PENDAHULUAN}

Kemajuan teknologi informasi dan ekonomi saat ini, menyebabkan terjadinya perubahan gaya hidup pada masyarakat. Perubahan tersebut juga berpengaruh pada perubahan pola makan. Kecenderungan mengkonsumsi makanan berkolesterol tinggi dan berlemak berisiko menyebabkan peningkatan kadar lipid dalam darah yang kita kenal dengan istilah hiperlipidemia. Gambaran yang paling sering didapatkan berupa peningkatan kadar kolesterol total, trigliserida, dan LDL, serta penurunan kadar HDL (Nasution et al., 2015).

Kebiasaan mengkonsumsi makanan berlemak memberi dampak gangguan antiseptik baru, seperti radang hati akibat perlemakan hati. Penyakit yang terjadi pada hati ini sulit diobati dan sering menahun hingga menyebabkan sirosis hati bahkan kanker hati dan berujung pada kematian. Hati merupakan organ sentral dalam antiseptik tubuh. Hati melakukan berbagai proses antiseptik terhadap konstituen konstituen darah yang mengalir kepadanya sebagai produk sisa atau zat gizi. Perlemakan hati (fatty liver) merupakan suatu pengumpulan lemak (lipid) yang berlebihan di dalam sel-sel hati (Krisnansari, 2014).

Gangguan fungsi hati dapat mengakibatkan terjadinya pembengkakan dengan adanya kenaikan enzim transaminase yang diproduksi oleh hati. Sehingga enzim ini dapat digunakan untuk menilai kelainan atau adanya gangguan pada fungsi hati. Pemeriksaan yang digunakan untuk mengetahui adanya kenaikan enzim transaminase yaitu dengan melakukan pemeriksaan Aspartat Aminotransferase (AST) atau Serum Glutamic Oxaloacetat Transaminase (SGOT) dan Alanin Aminotransferase (ALT) atau Serum Glutamic Pyruvate Transaminase (SGPT). Tingkat kerusakan yang terjadi pada hati dapat dilihat dari adanya peningkatan rasio ALT/AST lebih dari dua kali nilai normal (Suaniti, 2012).
Serum Glutamic Oxaloacetic

Transaminase (SGOT) merupakan suatu enzim yang dapat dijumpai dalam otot jantung dan hati. Antiseptik ditemukan dalam konsentrasi sedang pada otot rangka, ginjal maupun antiseptik. Saat terjadi cedera terutama pada sel-sel hati dan otot jantung, enzim ini akan dilepaskan ke dalam aliran darah. Fungsi utama enzim ini sebagai biomarker/penanda adanya gangguan pada hati dan jantung (Lomanorek et al., 2016).

Enzim aminotransferase adalah suatu enzim yang paling sering dihubungkan dengan kerusakan sel-sel hati. Dilakukan dengan pemeriksaan Alanin Aminotransferase (ALT) yang juga disebut Serum Glutamat Piruvat Transaminase (SGPT). Hati merupakan satu - satunya sel yang memiliki konsentrasi kadar SGPT yang tinggi sedangkan ginjal, otot jantung, dan otot rangka mengandung kadar SGPT yang sedang. SGPT dengan jumlah yang lebih sedikit lebih sering ditemukan di antiseptik, paru, limpa, dan eritrosit. Dengan demikian, SGPT memiliki spesifitas antiseptik yang lebih tinggi untuk mengetahui adanya kerusakan pada hati. Apabila sel-sel hati mengalami kerusakan, maka enzim akan banyak keluar ke ruang ekstra sel maupun ke dalam aliran darah. Pengukuran konsentrasi enzim di dalam darah dengan uji SGPT dapat memberikan informasi penting mengenai tingkat gangguan fungsi hati. Aktivitas kadar SGPT di dalam hati dapat dideteksi meskipun dalam jumlah yang sangat kecil (Kahar, 2017).

Daun kemangi (Ocimum basilicum L.) merupakan tanaman hijau alami dan dinilai memiliki antioksidan yang tinggi. Daun kemangi telah digunakan secara tradisional untuk pencegahan dan perawatan dari penyakit hati, memiliki efek ekspektoran, antiseptik dan digunakan sebagai obat batuk, demam, nyeri dan gangguan gastrointestinal (Lahon, 2011).

Daun kemangi memiliki $70 \%$ eugenol dan 21\% metil eugenol (Pandey et al., 2010). Eugenol berfungsi mengurangi 
peningkatan gula darah, trigliserida, kadar kolesterol, LDH, GPT, GOT dan alkalin fosfatase di serum darah. Daun kemangi memiliki kandungan seperti flavonoid, tannin dan saponin. Mekanisme antioksidan dari flavonoid yaitu menekan terbentuknya Reactive Oxigen Species (ROS) baik dengan inhibisi enzim atau dengan chelating trace element yang terlibat dalam pembentukan radikal bebas (Safitri, 2016).

Ekstrak dari daun kemangi dapat mengendalikan kerusakan hepatosit serta menurunkan lipid peroksidase dan meningkatkan antioksidan seperti Superoksida Dismutase (SOD), Catalase (CAT), glutation dan berpotensi sebagai hepatoprotektif sehingga dapat mencegah dan mengurangi kerusakan yang terjadi pada hati (Muslimin, 2015).

Berdasarkan penelitian sebelumnya menyatakan bahwa kemangi dengan dosis $200 \mathrm{mg} / \mathrm{kgBB} / \mathrm{hari}$ pada tikus albino memiliki efek hepatoprotektif (Lahon, 2011). Berbeda dengan Ganasoundari et al. (1999) yang menyatakan bahwa efek protektif daun kemangi bila diberikan dosis 300 mg/kgBB/hari (Rahman, 2011).

Penelitian yang dilakukan oleh Wahyudi et al. (2018) menyatakan ekstrak daun kemangi dengan dosis 1 (87,5 $\mathrm{mg} / \mathrm{kgBB})$, dosis 2 (175 $\mathrm{mg} / \mathrm{kgBB})$, dan dosis $3(350 \mathrm{mg} / \mathrm{kgBB})$ dapat menurunkan kadar enzim SGOT dan SGPT pada tikus yang diinduksi dengan Monosodium
Glutamat (MSG). Dosis ekstrak daun kemangi sebesar $350 \mathrm{mg} / \mathrm{kgBB}$ merupakan dosis yang paling optimal untuk menurunkan kadar enzim SGOT dan SGPT pada tikus yang diinduksi dengan MSG (Wahyudi et al., 2018).

Berdasarkan uraian latar belakang di atas, peneliti melakukan penelitian dengan judul studi literatur pengaruh pemberian ekstrak kemangi (Ocimum basilicum L.) terhadap kadar SGOT dan SGOT pada tikus putih (Rattus norvegicus) jantan galur Wistar yang diberi diet tinggi lemak. Penelitian ini bertujuan untuk mengetahui pengaruh pemberian ekstrak kemangi (Ocimum basilicum L.), dosis yang efektif dan lama pemberian dosis efektif dalam menurunkan kadar SGOT dan SGPT.

\section{METODE}

Penelitian ini merupakan penelitian kualitatif dengan menggunakan rancangan penelitian non eksperimental yang bersifat deskriptif. Data yang digunakan dalam penelitian ini adalah data dari literature review yang dianalisis secara deskriptif. Studi pustaka (literature review) menggunakan database PubMed dan ncbi.mlm.nih.gov dengan menggunakan kata kunci yang digunakan dalam pencarian data untuk menelusuri artikel jurnal yang terkait dengan ekstrak kemangi, SGOT, SGPT, tikus, dan diet tinggi lemak.

\section{HASIL}

Tabel 4.1 Daftar Pencarian Literature Review

\begin{tabular}{|c|c|c|c|c|c|c|}
\hline No & Peneliti & Tahun & Judul & Metode & $\begin{array}{c}\text { Lama } \\
\text { Penelitian }\end{array}$ & Hasil Penelitian \\
\hline 1 & $\begin{array}{l}\text { Saber A. Sakr., } \\
\text { Sabah F. El- } \\
\text { Abdullah., } \\
\text { Mohamed Osman, } \\
\text { Asmaa M. Kandil } \\
\text { dan Mona S. } \\
\text { Helmy. Journal of } \\
\text { American Science } \\
\text { Vol. } 7 \text { No. } 8 .\end{array}$ & 2011 & $\begin{array}{l}\text { Ameliorative } \\
\text { Effect of } \\
\text { Aqueous Leave } \\
\text { Extract of } \\
\text { Ocimum } \\
\text { basilicum on } \\
\text { CCl4 - Induced } \\
\text { Hepatotoxicity } \\
\text { and } \\
\text { Apoptosis in } \\
\text { Albino Rats. }\end{array}$ & $\begin{array}{l}\text { Penelitian } \\
\text { eksperimental yang } \\
\text { dilakukan pada tikus } \\
\text { Wistar albino jantan } \\
\text { seberat } 100 \pm 5 \text { gram, } \\
\text { disimpan di } \\
\text { laboratorium dalam } \\
\text { kondisi konstan } \\
\text { dengan suhu ( } 24 \pm 2 \\
\mathrm{C}^{\circ} \text { ) selama } \\
\text { setidaknya satu } \\
\text { minggu sebelum }\end{array}$ & 45 hari & $\begin{array}{l}\text { Hasil penelitian ini } \\
\text { menunjukkan CCl4 } \\
\text { menyebabkan } \\
\text { kerusakan pada } \\
\text { organisasi struktural } \\
\text { normal lobulus hati, } \\
\text { gangguan dan dilatasi } \\
\text { pembuluh darah, } \\
\text { sitoplasma vakuolisasi } \\
\text { hepatosit, infiltrasi } \\
\text { leukositik dan } \\
\text { degenerasi lemak. }\end{array}$ \\
\hline
\end{tabular}




\begin{tabular}{|c|c|c|c|c|c|c|}
\hline & & & & $\begin{array}{l}\text { penelitian. Data } \\
\text { dianalisis } \\
\text { menggunakan uji } \\
\text { ANOVA. }\end{array}$ & & $\begin{array}{l}\text { Hasil biokimia ekstrak } \\
\text { daun kemangi } \\
\text { menunjukkan terjadi } \\
\text { peningkatan serum } \\
\text { ALT, AST, ALP, } \\
\text { kolesterol, trigliserida, } \\
\text { LDL dan HDL. } \\
\text { Bahkan, CCl4 } \\
\text { menginduksi apoptosis } \\
\text { hati. }\end{array}$ \\
\hline 2 & $\begin{array}{l}\text { Galila A. Yacout., } \\
\text { Nihal M. } \\
\text { Elguindy dan } \\
\text { Eman F. El Azab. } \\
\text { African Journal of } \\
\text { Biotechnology } \\
\text { Vol. } 11 .\end{array}$ & 2012 & $\begin{array}{l}\text { Hepatoprotecti } \\
\text { ve Effect of } \\
\text { Basil (Ocimum } \\
\text { basilicum L.) } \\
\text { on CCl4 } \\
\text { Induced Liver } \\
\text { Fibrosis in } \\
\text { Rats. }\end{array}$ & $\begin{array}{l}\text { Penelitian ini } \\
\text { merupakan penelitian } \\
\text { eksperimental. } \\
\text { Analisa data } \\
\text { menggunakan } \\
\text { analisis varian } \\
\text { student's-test with } p \\
<0.001 \text {. }\end{array}$ & 42 hari & $\begin{array}{l}\text { Hasil penelitian ini } \\
\text { menunjukkan bahwa } \\
\text { ekstrak etanol kemangi } \\
\text { memiliki efek } \\
\text { hepatoprotektif yang } \\
\text { kuat pada fibrosis hati } \\
\text { yang diinduksi CCl4. } \\
\text { Mengontrol semua } \\
\text { parameter yang diuji } \\
\text { kecuali hidroksiprolin. } \\
\text { Selain itu, baik } \\
\text { kemangi dan Diphenyl } \\
\text { Dimethyl } \\
\text { Bicarboxylate (DDB) } \\
\text { memiliki efek } \\
\text { perbaikan pada } \\
\text { pengobatan tikus } \\
\text { fibrotik. }\end{array}$ \\
\hline 3 & $\begin{array}{l}\text { Ahmad Ali, } \\
\text { Muhammad } \\
\text { Qasim, } \\
\text { Muhammad } \\
\text { Nazar Aftab, } \\
\text { Sheikh } \\
\text { Muhammad } \\
\text { Azam, Furhan } \\
\text { Iqbal, Shehla } \\
\text { Akram dan } \\
\text { Muhammad } \\
\text { Zubair Hussain. } \\
\text { Pure and Applied } \\
\text { Biology Vol. } 6 \text { No. } \\
\text { 2. }\end{array}$ & 2017 & $\begin{array}{l}\text { Effects of } \\
\text { Ocimum } \\
\text { basilicum } \\
\text { Extract on } \\
\text { Hematological } \\
\text { and Serum } \\
\text { Profile of Male } \\
\text { Albino Mice } \\
\text { After AlCl3 } \\
\text { Induced } \\
\text { Toxicity. }\end{array}$ & $\begin{array}{l}\text { Penelitian ini } \\
\text { menggunakan metode } \\
\text { eksperimental pada } \\
\text { tikus albino. Analisis } \\
\text { data menggunakan uji } \\
\text { two sample t-test. }\end{array}$ & 16 hari & $\begin{array}{l}\text { Hasil penelitian ini } \\
\text { menunjukkan bahwa } \\
\text { ekstrak daun kemangi } \\
\text { mempengaruhi } \\
\text { beberapa jenis } \\
\text { parameter hematologi } \\
\text { seperti RBC, PLT, } \\
\text { LYM, MCH, NEU, } \\
\text { WBC, MCHC, MCH, } \\
\text { HCT, HGB dan } \\
\text { parameter serologis } \\
\text { seperti SGOT/SGPT } \\
\text { pada tikus dewasa } \\
\text { albino jantan setelah } \\
\text { toksisitas yang } \\
\text { diinduksi AlCl3. }\end{array}$ \\
\hline 4 & $\begin{array}{l}\text { Chinelo Ezeani, } \\
\text { Ifeoma Ezenyi, } \\
\text { Theophine Okoye } \\
\text { dan Charles } \\
\text { Okoli. Journal of } \\
\text { Intercultural } \\
\text { Ethnopharmacolo } \\
\text { gy Vol. } 6 .\end{array}$ & 2017 & $\begin{array}{l}\text { Ocimum } \\
\text { basilicum L. } \\
\text { Extract } \\
\text { Exhibits } \\
\text { Antidiabetic } \\
\text { Effects Via } \\
\text { Inhibition of } \\
\text { Hepatic } \\
\text { Glucose } \\
\text { Mobilization } \\
\text { and } \\
\text { Carbohydrate } \\
\text { Metabolizing } \\
\text { Enzymes. }\end{array}$ & $\begin{array}{l}\text { Penelitian ini } \\
\text { merupakan penelitian } \\
\text { eksperimental. } \\
\text { Analisa data } \\
\text { menggunakan uji One } \\
\text { Way ANOVA. }\end{array}$ & 28 hari & $\begin{array}{l}\text { Hasil penelitian ini } \\
\text { menunjukkan bahwa } \\
\text { ekstrak daun kemangi } \\
\text { dapat menurunkan } \\
\text { aktivitas serum ALP } \\
\text { sebangai hepatoseluler. }\end{array}$ \\
\hline 5 & $\begin{array}{l}\text { Agung Wahyudi, } \\
\text { Yenni Bahar dan }\end{array}$ & 2018 & $\begin{array}{l}\text { Pengaruh } \\
\text { Ekstrak Etanol }\end{array}$ & $\begin{array}{l}\text { Penelitian } \\
\text { eksperimental dengan }\end{array}$ & 14 hari & $\begin{array}{l}\text { Hasil penelitian ini } \\
\text { menunjukkan bahwa }\end{array}$ \\
\hline
\end{tabular}




\begin{tabular}{|c|c|c|c|c|}
\hline & $\begin{array}{l}\text { Paramita } \\
\text { Septianawati. } \\
\text { Jurnal Faculty of } \\
\text { Medicine, } \\
\text { University } \\
\text { Muhammadiyah } \\
\text { of Purwokerto. }\end{array}$ & $\begin{array}{l}\text { Daun Kemangi } \\
\text { (Ocimum } \\
\text { basilicum L. } \\
\text { folium) } \\
\text { Terhadap kadar } \\
\text { SGOT dan } \\
\text { SGPT Tikus } \\
\text { Putih (Rattus } \\
\text { norvegicus) } \\
\text { Strain Wistar } \\
\text { yang Diinduksi } \\
\text { MSG. }\end{array}$ & $\begin{array}{l}\text { rancangan post test } \\
\text { randomized } \\
\text { controlled group } \\
\text { design menggunakan } \\
25 \text { tikus yang terbagi } \\
\text { menjadi } 5 \text { kelompok, } \\
\text { yaitu A sebagai } \\
\text { kontrol negatif (K-), } \\
\text { B sebagai kontrol } \\
\text { positif (K+), C } \\
\text { sebagai perlakuan } 1 \\
\text { (P1), D sebagai } \\
\text { perlakuan } 2 \text { (P2), E } \\
\text { sebagai perlakuan } 3 \\
\text { (P3). Dosis MSG } 7 \\
\text { gr/kgBB selama } 14 \\
\text { hari dan dilanjutkan } \\
\text { dengan ekstrak etanol } \\
\text { daun kemangi dengan } \\
\text { dosis } 87,5 \text { mg/kgBB, } \\
\text { 175 mg/kgBB dan } \\
350 \text { mg/kgBB } \\
\text { diberikan selama } 10 \\
\text { hari. Data dianalisis } \\
\text { menggunakan uji One } \\
\text { Way Anova. }\end{array}$ & $\begin{array}{l}\text { pemberian ekstrak } \\
\text { etanol daun kemangi } \\
\text { dengan dosis } 350 \\
\text { mg/kgBB dapat } \\
\text { menurunkan kadar } \\
\text { SGOT dan SGPT pada } \\
\text { tikus yang diinduksi } \\
\text { MSG dengan dosis } 7 \\
\text { gr/kgBB. Rerata kadar } \\
\text { SGOT pada penelitian } \\
\text { dengan dosis } 350 \\
\text { mg/kgBB memiliki } \\
\text { efek penurunan yang } \\
\text { terbaik dan lebih } \\
\text { signifikan yaitu dengan } \\
\text { rata-rata } 75.00 \pm \\
\text { (15.330) dan nilai P } \\
\text { 0.096. Nilai rerata } \\
\text { kadar SGPT kelompok } \\
\text { dengan dosis } 350 \\
\text { mg/kgBB memiliki } \\
\text { efek penurunan yang } \\
\text { terbaik yaitu dengan } \\
\text { rata-rata nilai P 0.074 } \\
\text { dibandingkan dengan } \\
\text { dosis } 87,5 \text { mg/kgBB } \\
\text { dan dosis } 175 \\
\text { mg/kgBB yang juga } \\
\text { mengalami penurunan } \\
\text { namun kurang } \\
\text { signifikan. }\end{array}$ \\
\hline 6 & $\begin{array}{l}\text { Mohammad } 2018 \\
\text { Mahdi Zangeneh, } \\
\text { Akram Zangeneh, } \\
\text { Saman Salmani, } \\
\text { Rezvan } \\
\text { Jamshidpour dan } \\
\text { Fatemeh Kosari. } \\
\text { Comparative } \\
\text { Clinical } \\
\text { Pathology. }\end{array}$ & $\begin{array}{l}\text { Protection of } \\
\text { Phenylhydrazin } \\
\text { e-Induced } \\
\text { Hematotoxicity } \\
\text { by Aqueous } \\
\text { Extract of } \\
\text { Ocimum } \\
\text { basilicum L. in } \\
\text { Wistar Male } \\
\text { Rats. }\end{array}$ & $\begin{array}{l}\text { Penelitian ini } 15 \text { hari } \\
\text { menggunakan metode } \\
\text { eksperimental dan } \\
\text { data dianalisis dengan } \\
\text { uji ANOVA. }\end{array}$ & $\begin{array}{l}\text { Hasil penelitian ini } \\
\text { menunjukkan bahwa } \\
\text { data dianalisis dengan } \\
\text { software SPSS-21. } \\
\text { Beberapa dosis ekstrak } \\
\text { kemangi secara } \\
\text { signifikan (p } \leq 0,05) \\
\text { meningkatkan kadar } \\
\text { berat badan, leukosit, } \\
\text { neutrofil, monosit, } \\
\text { trombosit, RBC, Hb, } \\
\text { PCV, MCV, MCH, } \\
\text { MCHC, dan } \\
\text { mengurangi } \\
\text { peningkatan kadar } \\
\text { ALP, AST, ALT, } \\
\text { GGT, urea, kreatinin, } \\
\text { besi, ferritin, dan } \\
\text { eritropoietin } \\
\text { dibandingkan dengan } \\
\text { kelompok yang tidak } \\
\text { diobati. Sebagai } \\
\text { kesimpulan, hasil yang } \\
\text { diperoleh menunjukkan } \\
\text { sifat anti-anemia dan } \\
\text { antioksidan dari } \\
\text { ekstrak kemangi. }\end{array}$ \\
\hline 7 & $\begin{array}{l}\text { Alyae M. S. } \\
\text { Gabal. Annual }\end{array}$ & $\begin{array}{l}\text { Basil (Ocimum } \\
\text { basilicum L.) }\end{array}$ & $\begin{array}{l}\text { Penelitian ini } \\
\text { merupakan penelitian }\end{array}$ & $\begin{array}{l}\text { Hasil penelitian ini } \\
\text { menunjukkan bahwa }\end{array}$ \\
\hline
\end{tabular}




\begin{tabular}{|c|c|c|c|c|}
\hline & $\begin{array}{l}\text { Research and } \\
\text { Review in } \\
\text { Biology. }\end{array}$ & $\begin{array}{l}\text { and/or Celery } \\
\text { (Apium } \\
\text { graveolens L.) } \\
\text { Leaves } \\
\text { Aqueous } \\
\text { Extracts Role } \\
\text { in Opposition } \\
\text { to Drinking } \\
\text { Contaminated } \\
\text { Water Induced } \\
\text { Male Rats } \\
\text { Urinary Stones } \\
\text { and Renal } \\
\text { Deteriorations. }\end{array}$ & $\begin{array}{l}\text { eksperimental. Hasil } \\
\text { penelitian akan } \\
\text { disajikan dengan } \\
\text { melihat nilai mean } \\
\text { dan standar deviasi. } \\
\text { Kemudian hasil dats } \\
\text { dianalisis } \\
\text { menggunakan uji One } \\
\text { Way ANOVA } \\
\text { menggunakan SPSS } \\
\text { versi } 20 \text { dengan nilai } \\
\text { signifikan p<0,01. }\end{array}$ & $\begin{array}{l}\text { ekstrak daun kemangi } \\
\text { dan/atau seledri } \\
\text { menetralkan dan } \\
\text { memperbaiki } \\
\text { pembentukan batu } \\
\text { kemih dan kerusakan } \\
\text { ginjal yang terkait } \\
\text { dengan air minum yang } \\
\text { terkontaminasi dengan } \\
\text { ethylene glycol dan } \\
\text { ammonium chloride } \\
\text { karena kandungan } \\
\text { konstituen aktifnya } \\
\text { mengandung flavonoid } \\
\text { dan polifenol yang } \\
\text { dapat menurunkan } \\
\text { peningkatan enzim } \\
\text { ACP, ALP, ALT dan } \\
\text { AST. }\end{array}$ \\
\hline 8 & $\begin{array}{l}\text { Ilham Touiss, } 2021 \\
\text { Sabir Ouahhoud, } \\
\text { Mohamed } \\
\text { Harnafi, Saloua } \\
\text { Khatib, Oussama } \\
\text { Bekkouch, } \\
\text { Souliman Amrani } \\
\text { dan Hicham } \\
\text { Harnafi. } \\
\text { Evidence-Based } \\
\text { Complementary } \\
\text { and Alternative } \\
\text { Medicine. }\end{array}$ & $\begin{array}{l}\text { Toxicological } \\
\text { Evaluation and } \\
\text { Hepatoprotecti } \\
\text { ve Efficacy of } \\
\text { Rosmarinic } \\
\text { Acid-Rich } \\
\text { Extract from } \\
\text { Ocimum } \\
\text { basilicum L. }\end{array}$ & $\begin{array}{l}\text { Penelitian } \\
\text { eksperimental pada } \\
\text { wistar rats dengan } \\
\text { berat } 150-250 \text { gram. } \\
\text { Analisa data } \\
\text { menggunakan uji One } \\
\text { Way ANOVA. }\end{array}$ & $\begin{array}{l}\text { Hasil penelitian ini } \\
\text { menunjukkan ekstrak } \\
\text { daun kemangi kaya } \\
\text { asam ros marinic } \\
\text { menunjukkan efek } \\
\text { hepatoprotektif } \\
\text { terhadap kerusakan } \\
\text { hati akibat karbon } \\
\text { tetraklorida pada tikus. } \\
\text { Efek menguntungkan } \\
\text { dari ekstrak daun } \\
\text { kemangi kemungkinan } \\
\text { karena adanya asam } \\
\text { ros marinic yang } \\
\text { memiliki efek } \\
\text { menstabilkan } \\
\text { membran. }\end{array}$ \\
\hline
\end{tabular}

\section{PEMBAHASAN}

Penelitian ini adalah penelitian literature review yang menggunakan 8 artikel jurnal sebagai referensi literatur. Dari 8 artikel jurnal tersebut sebanyak 4 artikel jurnal menyatakan bahwa ekstrak etanol daun kemangi dapat menghambat peningkatan kadar SGOT dan SGPT pada tikus yang diinduksi MSG, namun secara statistik tidak signifikan (Wahyudi et al., 2018).

Ekstrak kemangi dapat mengurangi peningkatan kadar ALP, AST, ALT, GGT, urea, kreatinin, besi, ferritin, dan eritropoietin dibandingkan dengan kelompok yang tidak diobati. Sebagai kesimpulan, hasil yang diperoleh menunjukkan sifat anti anemia dan antioksidan dari ekstrak kemangi dengan dosis $20 \mathrm{mg} / \mathrm{kgBB}, 60 \mathrm{mg} / \mathrm{kgBB}$ dan 80 $\mathrm{mg} / \mathrm{kgBB}$ selama 15 hari. (Zangeneh et al., 2018). Ekstrak kemangi dengan dosis 200 $\mathrm{mg} / \mathrm{kgBB}$ selama 29 hari kaya asam ros marinic yang menunjukkan efek hepatoprotektif terhadap kerusakan hati akibat karbon tetraklorida pada tikus. Efek ini menguntungkan karena adanya asam ros marinic yang memiliki efek untuk menstabilkan membran (Touiss et al., 2021).

Ekstrak kemangi memiliki sifat nefroprotektif yang kuat terhadap cisplatin, sehingga dapat menurunkan gips tubular, peritubular dan kongesti glomerulus, sumbatan pembuluh darah, degenerasi epitel, edema interstitial, dan infiltrasi oleh 
sel inflamasi, yang merupakan ciri nekrosis tubular akut, pada perbandingan dengan kelompok yang tidak diobati (Zaveri et al., 2012).

Hasil penelitian ini menguji efek ekstrak etanol daun kemangi dalam menghambat peningkatan kadar SGPT. Kemampuan menghambat peningkatan rerata kadar SGPT menunjukan potensi ekstrak daun kemangi sebagai hepatoprotektor. Pemanfaatan ekstrak etanol daun kemangi perlu memperhatikan bahwa hubungan dosis dan respon tidak selalu positif yang artinya semakin tinggi dosis tidak selalu diikuti dengan peningkatan efek. Penelitian dengan dosis $350 \mathrm{mg} / \mathrm{kgBB}$ memiliki efektifitas lebih tinggi dibandingkan dengan dosis 87,5 $\mathrm{mg} / \mathrm{kgBB}$ dan $175 \mathrm{mg} / \mathrm{kgBB}$, namun dosis $87,5 \mathrm{mg} / \mathrm{kgBB}$ lebih efektif dibandingkan dengan $175 \mathrm{mg} / \mathrm{kgBB}$ selama 10 hari penelitian (Wahyudi et al., 2018).

Hubungan dan respon suatu zat aktif yang tidak selalu linear mungkin terjadi. Hubungan dosis dan respon obat sangat terkait dengan ketersedian dan karakteristik reseptor obat tersebut dalam menimbulkan suatu efek. Penurunan efek pada dosis yang lebih tinggi menunjukan terjadinya kejenuhan reaksi antar molekul obat dengan reseptornya sehingga peningkatan dosis tidak akan menyebabkan peningkatan efek yang timbul (Katzung et al., 2012).

Ekstrak etanol daun kemangi memiliki kandungan multi zat aktif, diduga di antaranya memiliki kemiripan gugus aktif sehingga dapat berikatan dengan reseptor yang sama untuk menimbulakan efek sinergis, maka efek kejenuhan lebih cepat terlihat dibandingkan dengan obat mono zat aktif. Beberapa penelitian obat herbal mengalami hubungan dosis dan respon yang tidak linear (Erwin et al., 2012).

Penurunan kadar SGOT dan SGPT pada penelitian Wahyudi et al. (2018) pada kelompok dengan pemberian ekstrak daun kemangi, kemungkinan disebabkan oleh efek kerja flavonoid. Kandungan flavonoid dalam ekstrak daun kemangi mempunyai kemampuan sebagai antioksidan. Flavonoid bekerja dengan menekan sistem enzim sitokrom P-450 maka akan menghambat pembentukan radikal bebas. Flavonoid dapat bersifat antioksidan karena memiliki gugus hidroksi fenolik dalam strutur molekulnya yang memiliki daya tangkap radikal bebas dan sebagai pengkhelat logam. Flavonoid akan melepaskan radikal hidrogen dan membangkitkan radikal baru yang relatif lebih stabil dan tidak reaktif karena adanya efek resonansi inti aromatis. Jumlah gugus $\mathrm{OH}$ pada flavonoid sangat mempengaruhi aktivitas antioksidan tersebut (Zhang et al., 2009).

Ekstrak etanolik daun kemangi menyebabkan peningkatan yang signifikan dalam kadar serum AST pada mencit albino jantan. Penelitian ini sesuai dengan hasil dari studi sebelumnya di mana ekstrak daun kemangi dan Ocimum gratissimum secara signifikan meningkatkan kadar serum AST. Dapat dikatakan bahwa Ocimum gratissimum dan ekstrak daun kemangi memiliki bahan kimia yang menyebabkan peningkatan serum AST (Essien et al., 2012). Namun, hasilnya juga demikian bertentangan dengan studi lain di mana ekstrak daun kemangi menurunkan serum AST dan ALT secara signifikan (Khoun et al., 2012).

Dari 8 artikel jurnal yang digunakan sebagai referensi terdapat 1 artikel jurnal yang menunjukkan bahwa ekstrak daun kemangi dengan dosis $200 \mathrm{mg} / \mathrm{kgBB}$ yang diberikan kepada tikus selama 45 hari dapat menyebabkan perbaikan, baik dalam histopatologis maupun perubahan biokimia yang diinduksi oleh CCl4 (Sakr et al., 2011). Terjadinya pola penurunan kadar SGOT dan SGPT, tetapi secara statistik penurunan tersebut tidak signifikan. Waktu yang diperlukan sel hati untuk regenerasi mulai dari terjadinya jejas sampai dengan sempurnanya proses regenerasi sel adalah 8-10 hari. Sedangkan pemeriksaan SGOT dan SGPT dilakukan pada hari ke 11 setelah pemberian ekstrak (Adriansyah et al., 2014). 
Terdapat 1 artikel jurnal yang menyatakan bahwa ekstrak kemangi dengan dosis $100 \mathrm{mg} / \mathrm{kgBB}$ dan 200 $\mathrm{mg} / \mathrm{kgBB}$ selama 15 hari perlakuan pada tikus albino mempengaruhi beberapa jenis parameter hematologi dan serologis pada tikus dewasa albino jantan setelah toksisitas yang diinduksi $\mathrm{AlCl} 3$ (Ali et al., 2017).

Terdapat 1 artikel jurnal yang menyatakan bahwa hasil yang diperoleh menunjukkan bahwa ekstrak daun kemangi memiliki peran penting dalam menurunkan hiperlipidemia pada hewan coba terutama konsentrasi kedua ekstrak daun kemangi dengan dosis $200 \mathrm{mg} / \mathrm{kgBB}$ mengalami peningkatan yang signifikan pada tingkat aktivitas AST, ALT, ALP dan GGT pada tikus yang diberi diet hiperkolesterolemia selama 60 hari (Nahal et al., 2012); (Otunula, 2010).

Selanjutnya dari 8 artikel jurnal ditemukan 1 artikel jurnal menyatakan bahwa ekstrak kemangi dengan dosis pada hewan coba $100 \mathrm{mg} / \mathrm{kgBB}$ selama 35 hari dan atau seledri (Apium graveolens L.) dapat menetralkan dan memperbaiki pembentukan batu kemih dan kerusakan ginjal yang terkait dengan air minum yang terkontaminasi dengan EG dan AC karena kandungan konstituen aktifnya termasuk flavonoid dan polifenol (Gabal et al., 2020).

\section{KESIMPULAN}

Berdasarkan hasil pencarian literature review, dapat disimpulkan bahwa terdapat pengaruh ekstrak kemangi terhadap kadar SGOT dan SGPT pada tikus putih jantan galur Wistar. Serta dosis pemberian ekstrak kemangi yang efektif dalam menurunkan kadar SGOT dan SGPT pada tikus putih jantan galur Wistar yang diberi diet tinggi lemak adalah $100 \mathrm{mg} / \mathrm{kgBB} \quad-350$ $\mathrm{mg} / \mathrm{KgBB}$. Lama pemberian ekstrak kemangi yang efektif dalam menurunkan kadar SGOT dan SGPT pada tikus putih jantan galur Wistar yang diberi diet tinggi lemak adalah selama 14 - 45 hari.

\section{UCAPAN TERIMA KASIH}

Penelitian ini dapat dilaksanakan dengann baik, berkat bantuan dan dukungan dari berbagai pihak, untuk itu peneliti mengucapkan terima kasih kepada Universitas Malahayati, pembimbing dan penguji, rekan - rekan penelitian, teman teman serta pihak terkait yang sudah memfasilitasi dan membantu berjalannya penelitian ini.

\section{DAFTAR PUSTAKA}

Adriansyah, H., Kamaludin, MT., Theodorus, T., Sulastri, H. (2014) 'Efek Hepatoprotektif Teripang Emas (Stichopus variegatus) pada Tikus Jantan Dewasa Galur Wistar yang Diinduksi Parasetamol Dosis Toksik'. Majalah Kedokteran Universitas Sriwijaya. 46, 136-143.

Ali, A., Qasim, M., Aftab, M., Azam, M et al. (2017) 'Effects of Ocimum basilicum Extract on Hematological and Serum Profile of Male Albino Mice After AlCl3 Induced Toxicity'. Pure and Applied Biology. 6(2): 505510.

Erwin, SC., Purwitasari, T. (2012) 'Uji Hipoglikemik Ekstrak Metanol Daun Majapahit (Crescentia Cujute L.) terhadap Kadar Glukosa Darah Mencit Jantan'. Jurnal Kimia Mulawarman.

Fitria, L., Sarto, M. (2014) 'Profil Hematologi Tikus (Rattus norvegicus Berkenhout, 1769) Galur Wistar Jantan dan Betina Umur 4, 6, dan 8 Minggu'. Biogenesis 2.

Gabal, Alyae MS. (2020) 'Basil (Ocimum basilicum L.) and/or Celery (Apium graveolens L.) Leaves Aqueous Extracts Role in Opposition to Drinking Contaminated Water 
Induced Male Rats Urinary Stones and Renal Deteriorations'. Annual Research and Review in Biology.

Galila, AY., Nihal, ME., Eman, FEA. (2012) 'Hepatoprotective Effect of Basil (Ocimum basilicum L.) on CCl4-Induced Liver Fibrosis in Rats'. African Journal of Biotechnology. 11. 15702-15711.

Kahar, H. (2017) 'Pengaruh Hemolisis Terhadap Kadar Serum Glutamate Pyruvate Transaminase (SGPT) Sebagai Salah Satu Parameter Fungsi Hati'. The Journal of Muhammadiyah Medical Laboratory Technologis Vol. 2. No. 1. 38-46.

Katzung, BG., Masters, SB., Trevor, AJ. (2012) 'Basic \& Pharmacology'. 12th Editon. The McGraw- Hill Companies Inc.

Krisnansari, D., Sulistyo, H., Ati, VR. (2014) 'Efek Propolis Terhadap Fungsi dan Perlemakan Hati Tikus (Rattus norvegicus) Model Hiperkolesterolemia'. Jurnal Penelitian Gizi Makanan Vol. 37.

Lahon, K., Das, S. (2011) 'Hepatoprotective Activity of Ocimum sanctum Alcoholic Leaf Extract Against Paracetamol-Induced Liver Damage in Albino Rats'. Journal of Pharmacognosy Research.

Lomanorek, VY., Assa, YA., Mewo, YM. (2016) 'Gambaran Kadar Serum Glutamic Oxaloacetic Transaminase (SGOT) Pada Perokok Aktif Usia >40 Tahun'. Jurnal e-Biomedik.

Muslimin, MB. (2015) 'Ekstrak Daun Kemangi (Ocimum Sanctum) Sebagai Hepatoprotektor Terhadap Kadar SGOT dan SGPT Mencit (Mus musculus) yang Diinduksi Isoniazid'.
Fakultas Kedokteran Universitas Jember.

Nahal, D., Thabet, H., Ahmed, S. (2012) 'Study The Impact of Sweet Basil Extracts (Ocimum basilicum L.) to Reduce Blood Cholesterol'. Egyptian Journal of Nutrition and Health Vol. 7 No. 1.

Nasution, AY., Adi, P., Santosa, PA. (2015) 'Pengaruh Ekstrak Propolis terhadap Kadar SGOT (Serum Glutamic Oxaloacetic Transaminase) dan SGPT (Serum Glutamic Pyruvic Transaminase) pada Tikus Putih (Rattus norvegicus) Galur Wistar dengan Diet Tinggi Lemak'. Majalah Kesehatan Fakultas Kedokteran Universitas Brawajiaya, Malang.

Otunola, GA., OB, Oloyede., AT, Oladiji., and AJ, Afolayan. (2010) 'Effects of Diet-Induced Hypercholesterolemia on The Lipid Profile and Some Enzyme Activities in Female Wistar Rats'. African Journal of Biochemistry Research. 4 (6): 149 154.

Pandey, G., Madhuri, S., Tulsi. (2010) 'Pharmacological Activity'. https://www.researchgate.net/deref/ht tp\%3A\%2F\%2Fwww.webmedcentral .com\%2Farticle_view\%2F1046. 9 September 2020 (15.43).

Putri, GS., Romdhoni, M., Bahar, Y. (2019) 'Pengaruh Ekstrak Etanol Daun Kemangi (Ocimum basilicum L) Terhadap Kadar Ureum dan Kreatinin Tikus Putih (Rattus norvegicus strain wistar) yang diinduksi MSG'. Universitas Muhammadiyah Purwokerto. Herb-Medicine Journal Vol 2. ISSN: 2620-567X. (1). 36-42.

Rahman S. (2011) 'Ocimum sanctum $L$. Phytochemical and Pharmacological 
Profile'. American Journal of Drug Discovery and Development.

Safitri, EE. (2016) 'Pengaruh Ekstrak Etanol Daun Kemangi (Ocimum sanctum) Sebagai Hepatoprotektor Terhadap Kadar MDA Hati Mencit yang Diinduksi Isoniazid'. Fakultas Kedokteran Universitas Jember.

Sakr, SA., El-Abd, SF et al. (2011) 'Ameliorative Effect of Aqueous Leave Extract of Ocimum basilicum on $\mathrm{CCl} 4$ - Induced Hepatotoxicity and Apoptosis in Albino Rats'. Journal of American Science.

Suaniti, Ni Made., Sudewa, D., Gede, AA., Suastika, K., Astawa, MN. (2012) 'Liver Damage Due To Alcohol Intoxication Repeat in Wistar Rats'. Jurnal Veteriner Vol. 13. No. 2.

Touiss, I., Ouahhoud, S., Harnafi, M. (2021) 'Toxicological Evaluation and Hepatoprotective Efficacy of Rosmarinic Acid-Rich Extract from Ocimum basilicum L.'. EvidenceBased Complementary and Alternative Medicine Volume 2021. Article ID 6676998. https://doi.org/10.1155/2021/6676998

Wahyudi, A., Bahar, Y., Septianawati, P. (2018) 'Pengaruh Ekstrak Etanol Daun Kemangi (Ocimum basilicum L.) Terhadap Kadar SGOT dan SGPT Tikus Putih (Rattus norvegicus strain wistar) yang diinduksi MSG'. Universitas Muhammadiyah Purwokerto. Herb-Medicine Journal Vol. 1. No. 1. ISSN: 2620-567X.

Zangeneh, MM., Zangeneh, A., Salmani, S et al. (2018) 'Protection of Phenylhydrazine-Induced Hematotoxicity by Aqueous Extract of Ocimum basilicum in Wistar Male Rats'. Comparative Clinical Pathology. https://doi.org/10.1007/s00580-0182845-8.

Zaveri, M., Desai, N., Movaliya, V. (2012) 'Effect of Ocimum basilicum on Cisplatin Models of Acute Renal Failure'. Advance Research in Pharmaceuticals and Biologicals. 1(2):91-100.

Zhang, HF., Yang, XA., Zhao, LD et al. (2009) 'Ultrasonic-Assisted Extraction of Epimedin C from Fresh Leaves of Epimedium and Extraction Mechanism'. Innovative Food Science and Emerging Technologies Vol. 10. 